małżeński. Autorka wykazuje, iż kobiety żyły krócej niż mężczyźni. Powodem była najczęściej śmierć przy porodzie. Danych w stosunku do napisów pogańskich jest stosunkowo dużo. Zespół tych informacji nie jest jednak na ogół uwzględniany przez literature naukowa dotyczącą rodziny chrześcijańskiej. Bazuje ona na przekazach Ojców Kościoła, które nie zawieraja tak dokładnych ujęć (aspekt małżeństwa), co umożliwia porównanie realiów i ideałów z życiem uchwyconym wprost.

Drugi artykuł traktujący o późnej chrześcijańskiej rodzinie rzymskiej autorstwa M. Kosznickiego, przedstawia aspekty życia rodzinnego występujące w źródłach narracyjnych u poety Auzoniusza (IV w.), który najpewniej był chrześcijaninem, lecz nie ma wystarczajacych danych na temat jego ewentualnej przynależności do Kościoła. Możemy tu porównać poezję narracyjna $z$ epigrafika, pokazujaca realia życia. Zasługa M. Kosznickiego jest zastosowanie przy analizie punktu widzenia pedagogiki, ale i znajomosć teoretycznych ujęć tworzacych ówcześnie Ojców Kościola.

Kolejne dwa opracowania W. Brzezińskiego i M. Chołodowskiej prezentuja średniowieczna rodzinę polska, jej życie codzienne $\mathrm{z}$ punktu widzenia źródeł prawniczych i dokumentów klasztornych. Duża wartością tych artykułów jest fakt, iż można je traktować jak pewnego rodzaju kronikę ówczesnych dziejów rodziny.

W artykule W. Brzezińskiego znajdujemy fragmenty piętnastowiecznych aktów sadowych z zakresu spraw małżeńskich, dotyczących próśb o unieważnienie małżeństwa. Głównym celem autora było przedstawienie dawnej praktyki prawnej Kościoła i sądu w odniesieniu do małżeństwa. Oprócz tego autor prezentuje nam indywidualne dzieje konkretnych ludzi połączonych wię- zami małżeństwa i to za pośrednictwem przytoczonych doslownie źródeł, co umożliwi studentom ich dalsza analizę.

Obraz polskiej rodziny średniowiecznej w Księdze Henrykowskiej przedstawia nam M. Chołodowska, przybliżając poglądy mnichów henrykowskich na temat małżeństwa, dzieci i dalszych krewnych.

Całość omawianego zbioru prac zamyka artykuł, raczej nie pasujacy do tego tomu, poświęcony wizerunkowi rodziny w latach 40 i 50, jaki kreowały ówczesne dzieła filmowe, napisany przez P. Zwierzchowskiego. Artykuł zawiera szkic problemu relacji rodzice-dzieci w filmach socrealistycznych. Autor opracowania za cel postawił sobie wykazanie różnicy relacji rodzicedzieci przedstawianych $w$ radzieckich i polskich filmach socrealistycznych, zestawiajac z tekstami politycznymi, naukowymi i literackimi.

Niewątpliwym walorem recenzowanej pracy jest różnorodność wykorzystanych i przeanalizowanych źródeł. Warto dodać, że użyteczność tych badań jest bardzo istotna, ponieważ aspekt funkcjonowania rodziny rzadko był omawiany na łamach publikacji naukowych.

Podsumowujac, Domus et Familia - ideaty i realia zycia rodzinnego jest publikacja stanowiacą istotną pomoc $w$ poznawaniu dziejów wychowania $w$ rodzinie. Forma narracji sprawia, że praca ta kierowana jest zarówno do historyków starożytnych czy wychowania, jak i do pedagogów, studentów lub czytelników słabiej orientujących się $w$ prezentujacych zagadnieniach. Bardzo dobre przygotowanie wydawnicze i edytorskie recenzowanej pracy, zachęca do jej przeczytania i glębszej analizy.

Wioletta Rudnicka

\title{
Historycy wychowania II Rzeczypospolitej, praca zbiorowa pod redakcją Władysławy Szulakiewicz, Studio Wydawnicze Familia, Warszawa 2000, ss. 192
}

Praca zbiorowa Historycy wychowania II Rzeczypospolitej pod redakcja Władyslawy Szulakiewicz wydana przez Studio wydawnicze ,Familia" w Warszawie w 2000 roku zawiera referaty przygotowane na konferencje naukowa na temat
Historycy wychowania II Rzeczypospolitej. Poglady - Postawy - Idee.

Teksty dotycza różnorodnej problematyki, a ich forma pisarska ma również różnorodny charakter: syntetyczny, jak i analityczny. Jako 
kryterium selekcji tych materiałów przyjęto sposób ujęcia przez Autorów podjętych zagadnień zwiazanych ściśle $\mathrm{z}$ tematem konferencji.

W pierwszej części zebrano teksty ukazujące zbiorowy wysiłek badawczy historyków wychowania okresu międzywojennego. W drugiej natomiast zgromadzono szkice i przyczynki poświęcone wybranym osobom, które związane były z dziejami oświaty i wychowania.

Pierwsza część pracy zatytułowana Kierunki i problematyka badań historyczno-oświatowych zawiera artykuły ukazujące główne kierunki badań, którymi zajmowali się międzywojenni historycy wychowania, ale także wskazuja na błędy i braki w tym zakresie.

Dział ten otwierają rozważania Władysławy Szulakiewicz na temat motywów zainteresowań badawczych historyków wychowania II Rzeczypospolitej. Autorka odpowiada na pytania: ,, Czego historycy wychowania, socjologowie, pedagogowie, filozofowie chcą się dowiedzieć analizując przeszłość? Czego poszukuja w przeszłości? Czy i jaka jest różnica mię̧dzy celami stawianymi w tej kwestii przez różnych specjalistów?"

Wśród motywów zainteresowań przeszłościa wymienia dwie zasadnicze grupy: poznawcze (naukowe) i praktyczne. Wśród tej ostatniej wyróżnia i analizuje motywy: kulturologiczny, ideologiczny, dydaktyczny, narodowy. Uzasadnia szczególna rolę motywów praktycznych w badaniu przeszłości oświatowo-wychowawczej. Autorka wskazuje, że w okresie dwudziestolecia międzywojennego w Polsce duże znaczenie $w$ badaniach historyczno-oświatowych miał motyw narodowy, który „był klamra łączaca pozostałe motywy". Pelnił on dwie funkcje: pozytywna i negatywna. „Pozytywna, ponieważ w jego imieniu tworzono podstawy patriotyczne wychowania narodowego" i negatywną, ponieważ „w jego imieniu wypaczano czasem prawdę o rzeczywistości oświatowej idąc w kierunku ideologii".

W zakończeniu działu Autorka podkreśla, iż motywy nie występują w czystej postaci, w odosobnieniu jako wzorcowe. Wskazuje, iż autorzy różnorodnych opracowań nie zawsze mieli samoświadomość, iż kierują się innym motywem aniżeli naukowy. Często $\mathrm{z}$ motywem poznawczym szedł w parze motyw dydaktyczny, kulturologiczny $i$ ideologiczny. Zawsze motywy praktyczne uzupełnialy naukowy motyw poznania.
Kończąc swoje rozważania słowami Sergiusza Hessena Autorka przedstawia zadanie historyka wychowania, które ,polega istotnie na tym, aby z pomnika rzeczowego wyprowadzić ukryty w nim sens, a przez to zrozumieć jako dzieło twórczości ludzkiej".

Dwa kolejne szkice przedstawiaja dorobek nad dziejami oświaty i myśli pedagogicznej określonych epok historycznych. Dorota Żołądź-Strzelczyk przedstawiła osiagnięcia $w$ badaniach nad dziejami edukacji staropolskiej w XX-leciu międzywojennym. Zaprezentowała dorobek poszczególnych ośrodków naukowych w: Krakowie, Lwowie, Warszawie i Poznaniu oraz działających w nich badaczy. Wymieniła ich sukcesy naukowe, a także wskazała na zaniedbania, które polegały na pomijaniu niektórych problemów i zbytnim koncentrowaniu się na wybiórczych zagadnieniach.

Autorka podkreśla, iż badacze okresu międzywojennego $w$ swych pracach nad dziejami oświaty staropolskiej wyraźnie pomijali problem dotyczący edukacji przedszkolnej i wczesnoszkolnej, a także rolę środowiska domowego w wychowaniu. W niewielkim zakresie zajmowali się również zagadnieniem edukacji kobiet.

Informuje również, iż $w$ tym okresie dominująca naukowa rolę $w$ badaniach nad dziejami oświaty i wychowania spełniała działalność Stanisława Kota, który był twórca krakowskiej szkoły historii kultury. Część badaczy dziejów edukacji staropolskiej zginęła tragicznie w czasie II wojny światowej: J. Frelichówna, ks. S. Bednarski, ks. K. Mazurkiewicz, a inni: H. Barycz, Ł. Kurdybacha kontynuowali swe prace po wojnie.

Dorobek czasopiśmienny dotyczący okresu oświecenia przedstawil Sławomir Sztobryn. Jego artykuł mieści się $w$ ramach czasowych wyznaczonych latami 1900 - 1939. W swoich rozważaniach Autor przedstawia ocenę poglądów i działalności najwybitniejszych myślicieli oświeceniowych w Polsce: H. Kolłątaja, S. Konarskiego, G. Piramowicza, T. Czackiego, S. Staszica, J. Śniadeckiego, F. Karpińskiego, I. Krasickiego dokonana przez takich badaczy jak: W. Hahn, T. Grabowski, B. Nytko, Z. Kukulski, H. Radlińska, L. Chmaj, A.J. Mikulski, R. Szajnerman, I. Chrzanowski, L. Kamykowski, F. Zych, F. Stopa, B. Nawroczyński. 
Szkic Jana Hellwiga ma nieco inny charakter, ponieważ autor skoncentrował się w nim na stworzeniu wizerunku poznańskiego ośrodka badań historyczno-oświatowych i wyeksponowaniu propozycji metodologicznych poznańskich historyków wychowania. Autor podkreślił, iż prace naukowo-badawcze poznańskich pedagogów zdeterminowane byly takimi podstawowymi czynnikami jak: bezpośrednic zainteresowania; zwiazek z integracją różnorodnej wiedzy kierowników katedry zdobytą w czasie studiów; osobiste doświadczenia szkolne; kontynuacja badań naukowych podejmowanych na innych uczelniach lub w czasie pracy w szkołach średnich i ich uzewnętrznienie w postaci publikacji; przemożny wpływ herbartyzmu i nowych kierunków w wychowaniu, a także idei wychowania narodowego.

Autor w swych rozważaniach omawia działalność Antoniego Danysza, Bogdana Nawroczyńskiego, Ludwika Jaxy-Bykowskiego oraz ks. Karola Mazurkiewicza, który wspierał prace naukowo-badawcze pracowników Katedry Pedagogiki Uniwersytetu Poznańskiego.

Kolejny tekst I rozdziału pracy autorstwa Tadeusza Jałmużny nosi tytuł Nauczyciele $z$ zakładów kształcenia nauczycieli jako historycy wychowania $w$ latach międzywojennych, ukazuje zbiorowy wysiłek badawczy nauczycieli seminariów nauczycielskich, pedagogiów i liceów pedagogicznych. Zwraca uwage na twórczość: Wandy Dzierzbickiej, Adolfiny Gorzyckiej-Wieleżyńskiej, Ludwiki Jeleńskiej, Julii Kisielewskiej, Salomei Kisielewskiej, Jadwigi Młodowskiej, Aleksandra Patkowskiego, Romualda Petrykowskiego, Wladysława Przanowskiego, Franciszka Śniechoty.

Wypowiedź tę autor traktuje jako wstęp do dalszych poszukiwań idei historycznych w dorob$\mathrm{ku}$ badawczym nauczycieli tych instytucji.

Ostatni artykuł tej części pracy przedstawia działania badawcze międzywojennych historyków wychowania w latach 1945 - 1956. Autorem tych rozważań jest Romuald Grzybowski, który za najważniejsze kryterium opracowania tego zagadnienia uznał poglądy polityczne twórców historiografii oświatowej i uwarunkowania polityczne rozwoju nauki polskiej.

Autor podkreśla, iż ,trudną sytuację historiografii wychowania pogłębiły zmiany polityczne zachodzace w Polsce po 1945 r., a zwlaszcza przejęcie w styczniu 1947 r. pełnej kontroli nad życiem spolecznym, naukowym i kulturalnym narodu przez PPR. Procesy te przesądziły o pelnym podporzadkowaniu pedagogiki polityce, o odrzuceniu dorobku pedagogiki polskiej okresu II Rzeczypospolitej i zastępowaniu go pedagogika komunistyczną zapożyczoną z ZSRR, o podziale pedagogów i myślicieli na ,reakcyjnych" i „postępowych" (rewolucyjnych).

Wśród historyków wychowania tego okresu wymienia: H. Barycza, J. Skoczka, J. Hulewicza, S. Tynca, C. Bobińska, Ł. Kurdybachę, W. Bobkowska, Z. Dulczewskiego, R. Wroczyńskiego, K. Maja, B. Suchodolskiego, S. Wołoszyna, K. Mrozowska, J. Dobrzańskiego, L. Hajdukiewicza, M. Chamcównę, J. Madeję, K. Trzebiatowskiego.

W cześci II zatytułowanej Historycy wychowania. Zainteresowania badawcze - poglady - postawy znajduja się szkice przedstawiajace międzywojenną historię wychowania przez pryzmat biografii: F. Majchrowicza, H. Radlińskiej, J. Hulewicza, J. Madei, S. Tynca, M. Janika.

Wśród zaprezentowanych postaci sa badacze znani, zajmujacy czołowe miejsce w rozwoju tej dyscypliny, jak i mniej znani, których prace zapisały się jednak na trwałe $w$ dorobku historiografii oświaty i wychowania.

Dział ten otwiera studium Andrzeja Meissnera poświęcone Franciszkowi Majchrowiczowi, który był jednym $\mathrm{z}$ prekursorów historii wychowania. Autor poddał rzetelnej ocenie wysiłek badawczy tego historyka wychowania. Podaje, iż zainteresowania naukowe F. Majchrowicza koncentrowały się wokół pedagogiki i psychologii. Wszystko, co opublikował na przełomie XIX i XX wieku dowodzi ścisłych związków z pedagogiką zachodniej Europy dążącej wówczas do przebudowy tradycyjnego systemu szkolnego. A. Meissner podkreśla iż poglady pedagogiczne F. Majchrowicza wyraźnie oscylowały w kierun$\mathrm{ku}$,nowych rozwiązań i nowego patrzenia na to, co wiąże się ze szkołą i jej społecznymi zadaniami".

Jego dorobek z zakresu historii myśli pedagogicznej i oświaty obejmuje według Meissnera około 30 różnych artykułów i rozpraw, wydawnictw źródłowych, dziesiątki recenzji prac historyczno-oswiatowych oraz podręczniki do historii wychowania przeznaczone dla zakładów kształcenia nauczycieli. 
Artykuł Wiesława Jamrożka przedstawia wszechstronny obraz dokonań w dziedzinie historii wychowania Heleny Radlińskiej. Autor ukazal w nim wklad H. Radlińskiej w kształtowanie się podstaw metodologicznych historii wychowania, a także podkreślił znaczenie jej dorobku piśmienniczego, w którym sporo miejsca zajmowała biografistyka edukacyjna. Autor podkreśla, iż „Helena Radlińska interesując się szczególnie dziejami oświaty pozaszkolnej i pracy społecznej znacznie poszerzała dotychczasowy przedmiot badań historii wychowania (sytuujacy się tradycyjnie wokół zagadnień szkolnych i tzw. pedagogiki szkolnej)". W jej stanowisku dostrzec można zalążki społecznej orientacji w badaniach historyczno-edukacyjnych. Akcentuje również jej wklad w rozwój badań regionalnych, gdyż „,bez ich wyników trudno kreślić większe obrazy przeszłości, ujmować szersze i bardziej całościowe problemy historii wychowania".

Kolejną część II działu stanowią rozważania Danuty Koźmian dotyczące Jana Hulewicza i jego miejsca w historii wychowania XX wieku. Autorka ukazała różnorodne formy i problematykę podejmowana przez Jana Hulewicza w jego pracy naukowo-badawczej. Przedmiotem zainteresowań Jana Hulewicza były zagadnienia oświaty i nauki w okresie zaborów oraz $w$ dwudziestoleciu międzywojennym: walka o szkołę polska w Galicji, walka kobiet polskich o dostęp do nauki i uniwersytetów, powstanie i rozwój Akademii Umiejętności, rola Szkoły Głównej w życiu narodu polskiego, dzieje Uniwersytetu Jagiellońskiego, znaczenie serii wydawniczej Biblioteka Narodowa dla rozwoju nauki i kultury, dzieje ruchu nauczycielskiego w Polsce, życie i dzialalność Stanislawa Łempickiego.
Kolejny artykul autorstwa Eleonory Sapii-Drewniak poświęcony jest Józefowi Madei, który zajmowal się problemami oświaty i wychowania dotyczącymi Śląska. Koncentrowal się on głównie wokól następujących problemów: walka o polskość i szkołę polska na Ślasku, działacze ruchu narodowego, dzieje elementarzy na Śląsku.

Autorka szkicu podkreśla, iż „chociaż zainteresowania naukowe J. Madei w zakresie historii oświaty ograniczone zostaly do regionu Śląska, to zawsze starał się on ukazywać problemy występujące $w$ tym regionie jako integralna częśc historii Polski".

W kolejnym szkicu Katarzyna Kalinowska przybliżyła działalność naukowa Stanisława Tynca, który rozwijał głównie zagadnienia zwiazane z dziejami szkolnictwa na Pomorzu. Jego publikacje wniosły poważny wkład $w$ historiografię Pomorza, a w szczególności Torunia. Zarówno jego praca naukowa, jak i dydaktyczna miały na uwadze krzewienie polskości. Publikujac szereg artykułów w ogólnodostępnej prasie popularyzował naukę akcentujac wartości moralne i narodowe.

Rozdział II kończy komunikat Tadeusza Jałmużny dotyczący Michała Janika, autora popularnego opracowania Dzieje szkolnictwa polskiego $z$ rzutem oka na jego przyszłość. Autor podkreśla, iż Michal Janik interesowal się historia oświaty, szkolnictwa i kultury polskiej, ponieważ świadczy o tym pozostawiony przez niego dorobek naukowy.

Trzecia część niniejszej pracy zatytułowana In Memoriam jest wyrazem szacunku dla niedawno zmarłych historyków wychowania: Profesor Mirosławy Chamcówny i Profesora Wacława Marmona.

Danuta Apanel

\section{Inspiracje dla współczesnej edukacji w dydaktyce Drugiej Rze- czypospolitej, pod red. Danuty Dryndy, Katowice 2000, ss. 130}

Publikacja Wydawnictwa Uniwersytetu Ślaskiego poświęcona koncepcjom teoretyczno-metodologicznym w dydaktyce Drugiej Rzeczypospolitej, dostarczajaca inspiracji dla wspólczesnej edukacji, stanowić będzie zapewne cenną pomoc dla osób zajmujacych się organizacją i rozwojem dzisiejszej dydaktyki.

Omawiana pozycja stanowi zbiór siedmiu artykułów, z których trzy pierwsze - Sławomira Sztobryna, Władysławy Szulakiewicz oraz Danuty 